Original Research Article

\title{
Working Period As A Moderating Variable Of Work Family Conflict, Work Stress, And Turnover Intention On Counterproductive Work Behavior
}

\author{
Dewi Puspa Amalia', Muhammad Zakiy ${ }^{2}$
}

${ }^{1,2}$ Sharia Economics Department, Faculty of Islamic study Universitas Muhammadiyah Yogyakarta

Article history: Recieved June 9 2021; Accepted September 24, 2021; Published October 16, 2021

HOW TO CITE: Dewi Puspa Amalia, Muhammad Zakiy (2021) (Working Period As A Moderating Variable Of Work Family Conflict, Work Stress, And Turnover Intention On Counterproductive Work Behavior), Vol 5 (2), October 2021, 202-212. DOI Link: http://doi.org/10.21070/perisai.v5i2.1363

\begin{abstract}
Counterproductive work behavior has caused a lot of harm to the organization and employees, both directly and indirectly. This research aims to determine the effect ofwork-family conflict, work stress and turnover intention on counterproductive work behavior with tenure as a moderator variable. This research using a purposive sampling technique and took 100 employees of BCA Syariah Bank by distributing questionnaires. The data obtained were analyzed using SmartPLS 3.3. The results of this research are work family conflict, and work stress has a positive effect on counterproductive work behavior, while turnover intention has a negative effect on counterproductive work behavior. The employees who want to resign will maintain their attitude by acting permanently or more productively than usual. The excuse is that employees avoid the penalties and keeps a good track record. In addition, tenuremoderates the effect of work-family conflict on counterproductive work behavior.
\end{abstract}

Keywords: Work Family Conflict, Work Stress, Turnover Intention, Tenure, BCASyariah.

*Corespondent e-mail address muhammad.zakiy@fai.umy.ac.id

Peer reviewed under reponsibility of Universitas Muhammadiyah Sidoarjo.

(C) 2021 Universitas Muhammadiyah Sidoarjo, All right reserved, This is an open access article under the CC BY license (http://creativecommons.org/licenses/by/4.0/) 


\section{INTRODUCTION}

In organizational development, human resources play a key role in success in realizing organizational goals as well as a measure of the ability to compete. As an intermediary financial institution, Islamic banks are required to have competent human resources with the application of Islamic values in their operational activities. Employees must provide careful and responsive services to customers so as not to reduce the value of service quality. In other words, employees must put aside some thoughts and responsibilitiesin other matters and focus on work professionalism.

The involvement of employees who are married in the work environment is recommended to formulate strategies inmanaging various affairs in both environments without reducing their obligations for both. The work and household will go hand in hand if there is a balance, understanding, andgood cooperation from the partner so that the two roles are carried out continuously in accordance with their portions. The negative impact of not creating strategies is the occurrence of inequality which causes one party to suffer a loss. With continuous physical and psychological burdens, employees have the possibility to experience work family conflicts.

Work family conflict (WFC) is a result of increased timeand energy devoted to the work and family environment so that it has the possibility of a conflict within employees (Buhali \& Margaretha, 2013similar to the role of a man whoacts as a father and husband and a woman who acts as a mother and wife sometimes sparking tension in determiningpriorities (Billah, 2018). Work family conflict is said to be one of the stressors that have a negative effect on the work environment and family (Amstad et al., 2011). Employees who experience work family conflicts (WFC) can cause the lack of employees' ability to position themselves in two environments that affect employees to commit acts of violence (Zahoor et al., 2019).

Employees with excessive workloads tend to have work stress (Billah, 2018). Excessive workloads cause inhibition of innovation which affects the employees' psychological condition, while the negative impact on the institution is thefailure to achieve goals due to decreased performance and productivity (Yang et al., 2000). Job stress is described as anemployee's inability to be responsible and fulfill a pile of tasks that causes discomfort in the work environment, and affects emotions, thought processes and individualconditions (Handoko, 2001). For employees who are married, work stress results in stress that can spread from work to home, or vice versa (Fender, 2010). Job stress can exacerbate physiological and psychological conditions that interfere with employee productivity and lead to fatal actions, such as crime and suicide (Aulia et al., 2019), as stated by the World Health Organization (WHO) that there was an $8 \%$ increase in physical illness and employees mentaldisease caused by work stress.

Employee discomfort due to conflict and self- incompatibility with the environment will lead to a desire toresign or look for a better job (Soeling \& Handoko, 2020; Zakiy, 2019). The problem of turnover intention is a problemthat requires special handling and should not be ignored by the institution because an increase in turnover intention will cause instability and a bad image that the institution's productivity does not work effectively (Lestari \& Mujiati, 2018). Not only that, institutions also need to spend more tocarry out the recruitment, selection, and retraining processesfor new employees whose work abilities are not necessarily the same as the previous ones. Turnover intention tends to be based on the level of job satisfaction and personality, and if the employee has a personality that does not impose personalwill and is able to accept the work environment as a whole, then the employee will avoid wanting to resign (Wah et al., 2012). Turnover intention causes employees to relinquish their responsibilities periodically and misbehave as a reaction to the uncertainty they face (Sabila, 2019). The tendency to immediately end his role as an employee in an unpleasant situation accompanied by a high workload and emotional tension will increase boredom (Sabila, 2019) and his intention to engage in deviant behavior (Julita \& Andriani, 2017).

Counterproductive work behavior is an act of violating norms that are done consciously and are detrimental to the organization or related stakeholders (Nurfianti \& Handoyo, 2013; Puspita \& Zakiy, 2020). Counterproductive work behavior that is triggered by work family conflicts, work stress and turnover intention disrupts mental health conditions and causes employees to lose direction to distinguish between beneficial and detrimental actions, thus taking actions out of control. Employees will only think of taking any action as a form of self-gratification because theiremotions don't go away. If employees do not have self- reinforcement and continue to commit deviant actions, then the institution has the possibility to get significant losses asa result of sabotage, theft, abuse, production deviance, and withdrawal (Spector et al., 2006) which are dimensions of counterproductive work behavior. The consequences that must be accepted by institutions for having counterproductive work behavior are cost losses and social psychological threats to the work environment (Darring,2016).

The effect of work family conflict on counterproductive work behavior is in the lack of an employee's ability to position himself in two environments so that it affects employee behavior to commit acts of violence (Zahoor et al., 2019) in an institutional or organizational environment (Counterproductive Work Behavior Organization) and atother individuals (Counterproductive Work Behavior Individual), such as colleagues or family members (Bennet \& Robinson, 2000). Furthermore, the linkage of work stressto counterproductive work behavior is based on thestatement of the Labor Force Survey (Aulia et al., 2019) in 2014, there were 440,000 cases of work stress in the UK, with 35\% 
of employees experiencing excessive workloads and ending up in fatal actions (criminal and committedsuicide). Meanwhile, the relation of turnover intention to counterproductive work behavior is based on the behavior ofemployees who wish to resign and tend to do detrimental activities, such as late arrival, absenteeism, or avoiding institutional associations (Novan \& Wahyuningtyas, 2020). To minimize the conflict between employees and the work environment, institutions need experienced employees. This means that employees have worked for a long time (Tarwaka, 2015) so that environmental suitability or the heavy-duty assigned is no longer a problem. The amount of experience is obtained from the length of time worked or known as the working period. If it is related to work family conflicts, tenure serves as a measure of employee professionalism in dealing with role conflicts that result in counterproductive work behavior. With the consideration oftenure, it is hoped that employees will be more skilled in sorting out which problems must be resolved first. This is done so that the emotions that arise in employees do not end in counterproductive work behavior that is detrimental to thefamily and the institution.

When associated with work stress, tenure plays a role in shaping the work personality of employees, thereby minimizing the occurrence of counterproductive work behavior. The intensity of the excessive burden of thoughts will endanger employees psychologically. Therefore, theinstitution provides skills training facilities in the hope that employees can be more skilled in completing the assigned task load and be able to create comfort with colleagues and the work environment. Generally, employees who have succeeded in obtaining comfort are employees who are already able to accept environmental conditions and arevulnerable to quite a long adjustment time.

In turnover intention, tenure plays a role as a factor that strengthens employees not to take deviant actions even though they have the desire to resign. This is because employees with a few years of service have not felt the benefits and attachments to the institution, such as those with long service tenure employees. When given an assignment that is considered burdensome to him, tenure employees feelbored a little faster and want to end their job immediately. The determination of employees to stay and avoid acts of deviance is obtained from the long working period.

The researcher chose BCA Syariah as the research object. With the vision of "To be the Mainstay and Choice of the Community's Sharia Bank", it is inevitable that BCA Syariah prioritizes the quality of service sourced from its employees.Even though the application of Islamic values has beencarried out, it is possible if employees who work at BCA Syariah experience contra with themselves. The reason for choosing the object of this research is that there are a significant increase and decrease in the number of employees with the working tenure category in the last two years.

The objectives of this study were to determine (1) the effect of work family conflict on counterproductive work behavior; (2) The effect of work stress on counterproductivework behavior; (3) The effect of turnover intention on counterproductive work behavior; (4) The working period moderates the effect of work family conflict on counterproductive work behavior; (5) The working period moderates the effect of work stress on counterproductive work behavior; and (6) tenure moderates the effect of turnover intention on counterproductive work behavior.

\section{CONCEPTUAL FRAMEWORK}

\section{Work family conflict on counterproductive work behavior}

Role conflict affects the level of decreased productivity (Ferguson et al., 2012), the level of saturation, emotional instability and deviant behavior (Hardiani et al., 2020). Employees who are in an uncertain position to prioritize family or work will cause an overload of thoughts. Therefore, employees tend to feel bored to be in that position, so that it will end up in counterproductive work behavior.

\section{H1 : Work family conflict has a positive effect on counterproductive work behavior}

\section{Work stress on counterproductive work behavior}

Job stress has a strong effect on counterproductive workbehavior (Bowling \& Eschleman, 2010). This deviant behavior often occurs in employees who have low scores onconscientiousness or the level of awareness to follow existing rules, as well as agreeableness or adaptation to the environment. Rotundo \& Spector (2010) stated that there arevarious stress-forming factors both in individuals and in the work environment, both of which have positive values on counterproductive work behavior. Therefore, employees who experience work stress need several abilities and formsof defense to protect themselves from harmful behavior(Fida et al., 2015).

\section{$\mathbf{H}_{2}$ : Job stress has a positive effect on counterproductive work behavior}

\section{Turnover intention towards counterproductive work behavior}

Counterproductive work behavior (CWB) is the expression of an employee because of his desire to resign (Chang et al., 2013). Employees who have difficulty resigning due to procedural limitations will show their desirethrough behavior, such as attendance and not completing assignments on time. Turnover intention is used as a prediction for counterproductive work behavior (Cohen et al., 2013). 
The working period as a moderator variable of the effectof work family conflict on counterproductive work behavior

$\mathrm{Ng} \&$ Feldman (2008) stated that employees with high tenure tend to distance themselves from counterproductive work behavior. According to him, employees who haveworked for a long time will have a stock of experience and tend to dedicate themselves to the institution, whereas employees with low tenure apply the opposite. In addition, employees who have worked for a long time are also more committed to the organization and are even willing to buy company shares (Chisaan \& Zakiy, 2020). This is based on the level of the employee's ability to manage his role and business in fulfilling the obligations of the two environmentssimultaneously.

$\mathrm{H}_{4}$ : The working period moderates the effect of work family conflict on counterproductive work behavior

The working period as a moderator variable of the effectof work stress on counterproductive work behavior

Employees with long working tenure will be more at riskof experiencing work stress in the moderate category, which results in decreased productivity behavior (productiondeviance) which is part of counterproductive work behavior(Budiyanto \& Pratiwi, 2010). According to him, tenure will be one of the triggers for stress and deviant actions that are detrimental to many parties if there is a negative employee work experience. However, if employees have a good fit with the environment, a long period of work will give employees immunity to stress.

\section{H5 : The working period moderates the effect of work stress on counterproductive work behavior}

The working period as a moderator variable of the effectof turnover intention on counterproductive work behavior

The role of tenure in the desire to resign and counterproductive work behavior is divided into emotional and experiential (Kanfer et al., 1988). Employees with a short tenure lack experience and emotional stability, and thedesire to resign is observable through frequent absences. Meanwhile, during the long working period, employees already have a lot of experience and emotional stability, so that the description of the desire to resign by engaging in counterproductive work behavior is minimal. However, thiswill turn out to be possible if the long-term employee is already bored with his job.

H6 : The working period moderates the effect of turnover intention on counterproductive work behavior

\section{METHOD (FOR RESEARCH ARTICLE)}

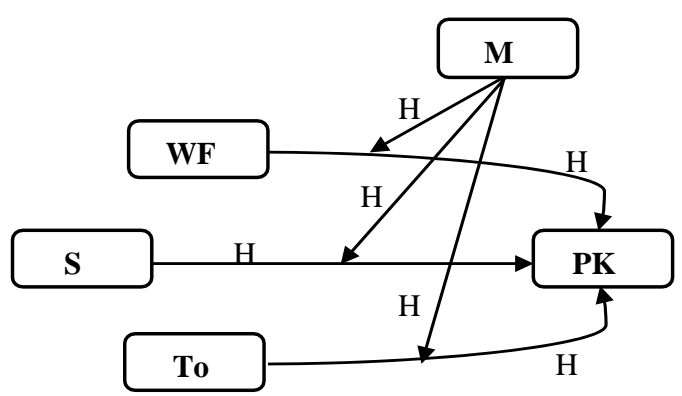

Figure 1 Research Model

This study used a causal-type explanatory design to findand examine a cause-and-effect relationship between two ormore variables (Huda \& Mulyana, 2018). The quantitative approach was carried out by testing certain theories on the relationship between variables consisting of numbers and analysis based on statistical procedures (Huda \& Mulyana, 2018). This study analyzed tenure as a moderator variable for the effect of work family conflict, work stress, and turnoverintention on counterproductive work behavior amongemployees of PT. BCA Syari'ah.

Sekaran (2006) described the population as a group or collection of subjects or objects that will be generalized intothe results of research. The population in this study was employees of PT. BCA Syariah located in DKI Jakarta.

The samples were obtained from the non-probabilitysampling method with purposive sampling or by determining the target population criteria, which were married employees. Hair et al. (Rohmah et al., 2020) stated that the minimum sample size is 100-200 depending on the number of variables estimated. Guidelines in determining the numberof samples 
are 5-20 times the number of variables or indicators. In this study, there are five variables, including (a) Work family conflict, (b) Job stress, (c) Turnover intention, (d) Counterproductive work behavior, and (e) Working period. Consequently, 100 respondents were takenas samples (5 variables X 20).

\section{Data Collection}

The type of data in this study was primary data obtainedfrom a digital questionnaire via Google Form distributed to 100 BCA Syariah employees. The type of questionnaire wasa structured (closed) questionnaire so that the researcher gotanswers in the form of a scaled weight assessment of the matrix questions. The measurement for work family conflict(six indicators), work stress (six indicators), turnover intention (six indicators) and counterproductive work behavior (five indicators) used a Likert scale as follows, $5=$ Strongly Disagree; 4 = Disagree; $3=$ Neutral; $2=$ Agree; $1=$ Strongly Agree. In comparison, the measurement of workingtenure uses a dummy with a value of $0=<3$ years belong toshort work period and 1 => 3 years belong to long work period (Elia et al., 2016).

\section{Data Analysis}

In testing the hypothesis, this study used the Structural Equation Model (SEM) based on Partial Least Square (PLS). With the help of the SmartPLS 3.3 program, the analysis technique was divided into two stages (Sury, 2020), 1) Testing the measurement model (outer model) or reflective measurement by testing the validity and reliability of the constructs of each indicator, concerning the value parametersof convergent validity, discriminant validity, composite reliability and Cronbach's alpha. At this testing stage, researchers might reduce or estimate data that did not support the level of validity and reliability, and 2) Structural model test (inner model) to determine the correlation between constructs regarding parameters of the R-Square Adjusted value, the T-statistic value and the p-value on the path coefficients.

\section{RESULTS AND DISCUSSION}

\section{Results}

\section{Outer Model Evaluation}

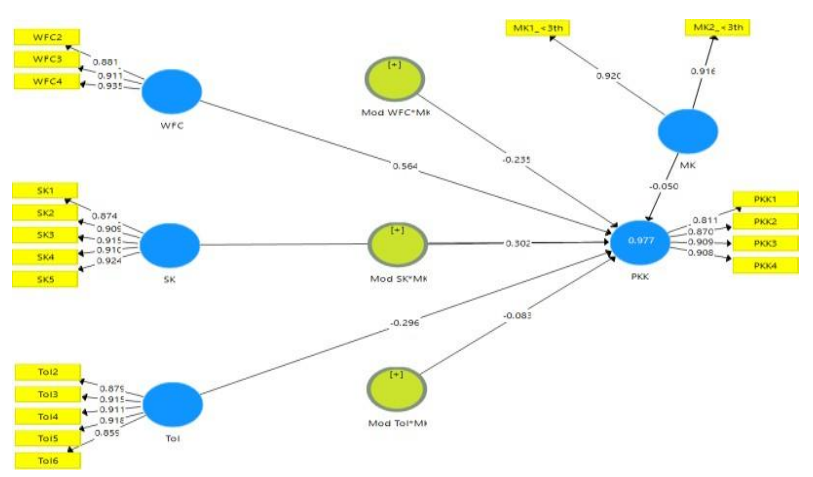

Figure 2 Output Outer Model Re-estimation

a) Convergent Validity

After doing the first test on convergent validity by looking at the outer loading value and AVE, several indicators did not meet the criteria (outer loading <0.7), therefore re-estimating the model and producing a re- estimation model output in Figure 2. The result of this test is all indicators meet the valid criteria (outer loading $>0.7$ and AVE> 0.5).

\begin{tabular}{l|l} 
TABLE 1 & Average Variance Extracted (AVE)
\end{tabular}

\begin{tabular}{|l|l|}
\hline Constructs & AVE Value \\
\hline Work Family Conflict & 0.826 \\
\hline Work Stress & 0.822 \\
\hline Turnover Intention & 0.804 \\
\hline Counterproductive Work Behavior & 0.766 \\
\hline Work Period & 0.843 \\
\hline \multicolumn{2}{|l}{} \\
\hline
\end{tabular}


b) Discriminant Validity

TABLE 2 Discriminant Validity

\begin{tabular}{|l|c|}
\hline \multicolumn{1}{|c|}{ Construct } & Discriminant Validity \\
\hline Work Family Conflict & 0.909 \\
\hline Work Stress & 0.906 \\
\hline Turnover Intention & 0.896 \\
\hline Counterproductive Work Behavior & 0.875 \\
\hline Work Period & 0.918 \\
\hline
\end{tabular}

From the test results in table 2, it can be seen that all constructs have the highest correlation value on their own constructs compared to other constructs, so that a value> 0.7 in one construct is declared to meet the discriminant validity requirements. Based on the values of convergentvalidity and discriminant validity that meet the rule of tumbs, testing the outer model of all constructs is declared to have good validity.

c) Composite Reliability

TABLE 3 Composite Reliability

\begin{tabular}{|l|c|}
\hline \multicolumn{1}{|c|}{ Constructs } & Composite Reliability \\
\hline Work Family Conflict & 0.934 \\
\hline Work Stress & 0.958 \\
\hline Turnover Intention & 0.953 \\
\hline Counterproductive Work Behavior & 0.929 \\
\hline Work Period & 0.915 \\
\hline
\end{tabular}

From the calculation of composite reliability in table 3 , all constructs have a value in accordance with the ruleof tumbs> 0.6, so this calculation is declared reliable.

d) Cronbach's Alpha

TABLE 4 Cronbach's Alpha

\begin{tabular}{|l|l|}
\hline Cronbach's Alpha & Value \\
\hline Work Family Conflict & 0.894 \\
\hline Work Stress & 0.945 \\
\hline Turnover Intention & 0.938 \\
\hline Counterproductive Work Behavior & 0.898 \\
\hline Work Period & 0.814 \\
\hline
\end{tabular}

From the test results in table 4, it can be seen that all constructs have a value that matches the criteria forCronbach's alpha> 0.6. Based on the value of compositereliability and Cronbach's alpha that meets the rule of tumbs, testing the outer model of all constructs is reliable(Zakiy, 2021).

\section{Inner Model Evaluation}

From the results of data processing using bootstrapping, the results of the coefficient of determination (R2) are intended to determine the magnitude of the effect of exogenous or independent variable values that can be explained on endogenous or dependent variables (Sury, 2020). Ghozali (2011) recommends research using the R- Square Adjusted value because the R-Square Adjusted valuecan change when adding one variable to the model. The R-Square Adjusted value can be seen in the original sample column (Zunianto \& Fauzan, 2017).

TABLE 5 R-Square Adjusted

\begin{tabular}{|l|c|}
\hline & R - Square Adjusted \\
\hline Counterproductive Work Behavior & 0.975 \\
\hline
\end{tabular}

From the test results in table 5, it can be seen that the R-Square Adjusted value for the counterproductive work behavior variable $(\mathrm{PKK})$ is 0.975 . The acquisition of this value explains that the percentage of counterproductive work behavior variables that can be influenced by the variables of work family conflict, work stress and turnover intention is $97.5 \%$, and the remaining $2.5 \%$ is explained by variables outside the research model. 


\section{Hypothesis Tests}

Hypothesis testing requires three main parameters in theinner model using bootstrapping techniques, including the original sample value $(\beta)$, which functions to determine the direction of influence between constructs, T-statistics whichfunctions to measure the significance of the hypothesis and the p-value, which functions to measure the significance of the hypothesis with different levels of significance (Sury, 2020).

TABLE 6 Path Coefficients

\begin{tabular}{|l|c|c|c|}
\hline & Original Samples $(\boldsymbol{\beta})$ & T-statistic (two-tiled) & p-value (10\%) \\
\hline WFC -> PKK & 0.563 & 4.354 & 0.000 \\
\hline SK -> PKK & 0.742 & 4.286 & 0.000 \\
\hline ToI -> PKK & -0.296 & 2.449 & 0.014 \\
\hline WFC * MK -> PKK & -0.234 & 1.834 & 0.066 \\
\hline SK * MK -> PKK & 0.301 & 1.529 & 0.126 \\
\hline ToI * MK -> PKK & -0.083 & 0.739 & 0.459 \\
\hline
\end{tabular}

The results of the analysis show that work family conflicthas a positive effect on counterproductive work behavior. The T-statistics value is $4.354 \geq 1.64$, the effect is significant, and the $p$-value is $0.000(0.00001) \leq 0.1$, which means that ithas a positive effect, and the positive direction of the originalsample value $(\beta)$ is 0.563 . Therefore, hypothesis one is accepted.

Job stress has a positive influence on counterproductive work behavior. The T-statistics value is $4.286 \geq 1.64$, the effect is significant, and the p-value is $0.000(0.00002) \leq 0.1$, which means that it has a positive effect and the positive direction of the original sample value $(\beta)$ is 0.742 . Therefore, hypothesis two is accepted.

The turnover intention has a negative effect on counterproductive work behavior. The original sample value $(\beta)$ is -0.296 with a negative direction (-) which indicates thatit is not in line with the hypothesis. The T-statistics value is $2.449 \geq 1.64$, and the $p$-value is $0.014 \leq 0.1$, which means that it has a significant effect. The turnover intention has an effect on counterproductive work behavior, but the direction of the original sample is negative. Therefore, hypothesis three is rejected.

The work period moderates work family conflict oncounterproductive work behavior. The original sample value $(\beta)$ is -0.234 which means it is debilitating, the T-statistics value is $1.834 \geq 1.64$, and the $p$-value is $0.066 \leq 0.1$ which means that it has a significant effect. The working period ofthis hypothesis is the quasi moderator (Bryan \& Haryadi, 2018), a moderating variable that has a role as a moderator and becomes an exogenous variable. Therefore, hypothesis four is accepted.

The working period does not moderate work stress on counterproductive work behavior. The T-statistics value is $1.529 \leq 1.64$, the effect is not significant, and the p-value is $0.126 \geq 0.1$, which means it is not moderate, and the originalsample value $(\beta)$ is 0.301 . The working period of this hypothesis is a predictor moderator (Bryan \& Haryadi, 2018), namely a moderating variable that has a role as an exogenous variable in the model but does not act as a moderator. Therefore, hypothesis five is rejected.

The working period does not moderate turnover intention towards counterproductive work behavior. The Tstatistics value is $0.739 \leq 1.64$, the effect is not significant, and the p-value is $0.459 \geq 0.05$, which means that the working period does not moderate, and the original sample value $(\beta)$ is -0.083 . The working period of this hypothesis is a predictor moderator (Bryan \& Haryadi, 2018), a moderating variable that has a role as an exogenous variable in the model but does not act as a moderator. Therefore, hypothesis six is rejected.

\section{The relationship of work family conflict with counterproductive work behavior}

Employees who are married and act as spouses or parentsand workers will find it difficult to be responsible for two environments. The existence of burdens in different contextsbut at the same time will create a feeling of dilemma in prioritizing interests. Employees who experience work family conflicts will feel physical and psychological fatigue, which can lead to acts of irregularities. The results of this study are in line with the statement of Ferguson et al. (2012) that employees who have conflicts tend to isolate themselvesand are filled with anger due to emotional instability and confusion of thought so that they have the highest level of vulnerability to decrease productivity for two main reasons, pressure on employees to reduce their desire to be involved in work and the occurrence of injustice on one of the partieswhich are causing the loss.

\section{The relationship between work stress andcounterproductive work behavior}

Work stress that occurs in employees, both due to problems in the work environment (organizationalconstraints) 
and themselves and colleagues (interpersonal constraints) and workload, can lead employees to engage in counterproductive work behavior. Job stress is a natural andcommon thing because there is pressure that may not be in accordance with the abilities or capabilities of the individual.Besides that, there is no appreciation in the form of compensation or support from the surrounding environmentresulting in poor interpersonal communication. The results of this study are in line with the statement of Aftab \& Javeed(2012) that untreated work stress will lead employees to behave inappropriately, attend, and act at will so that small losses will continue to develop into big losses, as well as problems that happens to colleagues who, if not fixed, will continue to develop into organizational problems.

\section{The relationship between turnover intention and counterproductive work behavior}

In some conditions, employees who wish to resign still feel that they have responsibilities that must be resolved. Employees who experience this dilemma actually act permanently or are more productive than usual. This is due to the thought of completing the task in a short time and being able to leave the job as soon as possible with a sense of peace and respect. In addition, there are penalties for leaving the deadline for the work contract and material needs that must be met so that employees stay, at least until they find a job that is more feasible to undertake. Employees whohave a positive response to their desire to resign will maintain their attitude and avoid counterproductive work behavior so as not to give a wrong impression when leaving their job.

\section{The relationship between working tenure as a moderatorfor work family conflict on counterproductive work behavior}

With the calculation of tenure, employees who experience role conflicts tend to discourage their intention totake harmful actions. Dirican \& Erdil (2016) state that long-term employees have emotional control and avoid engagingin counterproductive work behavior, and try to balance the two roles they play. In addition, employees are already accustomed to situations and problems from the work environment and family that come simultaneously, and this is because old employees already have different patterns of interpretation and appropriate strategies for overcoming this role conflict compared to employees who have worked a little. Employees with few tenures have a high probability of absenteeism and decreased productivity because they tend not to focus on career development as long-term employees do.

\section{The relationship between tenure as a moderator of workstress on counterproductive work behavior}

Employees who work for an institution will experience job stress. This pressure will not stop throughout the career path. Employees who enter their first employment period will feel pressured because they have to understand the direction of the assignment as quickly as possible, especiallyif it is not in accordance with their background or talent interests, so that job stress is likely to occur. Likewise, employees who have worked for long periods of time have to feel a job rotation. As a result, employees who are comfortable and master a field must learn new fields that may be more burdensome for employees so that job stress occurs. The existence of work stress sessions that every employee must experience will lead him/her to engage in counterproductive work behavior. Therefore, working tenureis not appropriate to weaken the influence of work stress on counterproductive work behavior.

\footnotetext{
The relationship between tenure as a moderator ofturnover intention on counterproductive work behavior The desire to resign can occur in new employees as well

as old employees. In accordance with its nature, the desire tomake a voluntary resignation can be avoided (avoidable voluntary turnover) generally occurs in employees who worka little because employees often make comparisons betweenprofessions and compensation with one another, causingunsteadiness to settle in jobs that have already been worked.Likewise, the nature of the desire to make an unavoidable voluntary turnover that generally occurs in employees who have worked for long periods, for example, employees who have to make adjustments to health conditions or householdconditions. The fast length of the employee's tenure cannot prevent the employee's desire to resign and commit deviant actions. Therefore, working tenure is not appropriate toweaken the effect of turnover intention on counterproductivework behavior.
}

\section{CONCLUSIONS}

Based on the test results, it can be seen that work familyconflict and work stress have a positive effect on counterproductive work behavior. Employees who have problems due to the imbalance of roles in the family and work environment and workloads beyond their abilities willcommit deviant actions that harm themselves and the institution. The turnover intention has a negative effect on counterproductive work behavior. This shows that employees do not engage in counterproductive workbehavior as an expression of their desire to resign. Period of work weakens the effect of work family conflict on counterproductive work behavior, meaning that the longer the employee stays in a job, the more skilled the employee isto position himself and manage responsibility for two environments at the same time. However, tenure has not been able to weaken the effect of work stress and turnover intention on counterproductive work behavior. 


\section{ACKNOWLEDGMENTS}

Researchers appreciate BCA Syariah for givingpermission and being research respondents.

\section{DAFTAR PUSTAKA}

Aftab, H., \& Javeed, A. (2012). The Impact of Job Stress on the Counter-productive Work Behavior (CWB) A Case Study from The Financial Sector of Pakistan. Interdisciplinary Journal of Contemporary Research in Business 4, $590-604$.

Amstad, F.T., Meirer, L.L., Fasel, U., Elfering, A., \& Semmer, N.K. (2011). A Meta-Analysis of Work-Family Conflict andVarious Outcomes With a Special Emphasis on Cross Domain Versus Matching-Domain Relations. Journal of Occupational Health Psychology 16, $151-169$.

Aulia, L., Kawatu, Paul .A.T., \& Langi, F.L.G. (2019). Hubungan Antara Beban Kerja dan Masa Kerja dengan Stres Kerja pada Security Check Point di PT Angkasa Pura I Bandar Udara Internasional Sam Ratulangi Manado. Medical Scope Journal 1,16 - 20.

Bennet, R.J., \& Robinson, S.L. (2000). Development of a Measure of Workplace Deviance. Journal of Applied Psychology92, $410-424$.

Billah, F.A. (2018). Pengaruh Konflik Peran Ganda dan Stres Kerja terhadap Kinerja Dosen Wanita di Institut Agama Islam(IAIN) Jember. Skripsi Gelar Sarjana. Universitas Jember.

Bowling, N.A., \& Eschlema, K.J. (2010). Employee Personality as a Moderator of the Relationships between Work Stressorand Counterproductive Work Behavior. Journal of Occupational Health Psychology 11, 145 - 156.

Bryan \& Haryadi, E. (2018). Analisis Pengaruh Variabel Moderasi Switching Costs terhadap Hubungan Service Performancedan Customer Loylity Member Celebrity Fitness Jakarta. Jurnal Manajemen 15, 52 - 71.

Budiyanto, T., \& Pratiwi, E.Y. (2010). Hubungan Kebisingan dan Masa Kerja Terhadap Terjadinya Stres Kerja Pada PekerjaDi bagian Tenun “Agung Saputra Tex” Piyungan Bantul Yogyakarta. KES MAS 4, 76 - 143.

Buhali, G.A., \& Margaretha, M. (2013). Pengaruh Work Family Conflict Terhadap Komitmen Organisasi: Kepuasan Kerja sebagai Variabel Mediasi. Jurnal Manajemen 13, 15 - 34.

Chang, W. J. A., Wang, Y. S., \& Huang, T. O. (2013). Work Design Related Antecedents of Turnover Intention: A MultilevelApproach. Human Resource Management 52, 1 - 26.

Chisaan, A. R., \& Zakiy, M. (2020). Employee Stock Ownership as Strategy to Improve Employee Performance (Case ofBank Syariah Mandiri Yogyakarta). JEBIS (Jurnal Ekonomi dan Bisnis Islam) 6, 42-59.

Cohen, T. R., Panter, A. T., \& Turan, N. (2013). Predicting Counterproductive Work Behaviour from Guilt Proneness. Journal of Business Ethics 114, 45-53.

Darring, S.,A. (2016). Pengaruh Trait Kepribadian, Locus of Control, dan Stresor Kerja terhadap Perilaku Kerja Kontraproduktif. Skripsi Gelar Sarjana. Universitas Islam Negeri Syarif Hidayatullah Jakarta.

Dirican, A.H., \& Erdil, O. (2016). An Exploration of Academic Staff's Organizational Citizenship Behavior and Counterproductive Work Behavior in Relation to Demographic Characteristics. Procedia Social and Behavioral Sciences $235,351-360$.

Elia, P.K., Josephus, J., \& Tucunan, A.T. (2016). Hubungan Antara Kelelahan Kerja dan Masa Kerja Dengan Produktivitas Kerja Pada Tenaga Kerja Bongkar Muat Di Pelabuhan Bitung Tahun 2015. PHARMACON : Jurnal Ilmiah Farmasi - UNSRAT5, 107 - 113.

Fender, C.M. (2010). Eelectronic Tethering: Perpetual Wireless Connectivity to the Organization. Thesis for the degree.

Drexel University.

Ferguson, M., Carlson, D., Hunter, E.M., \& Whitten, D. (2012). A Two-Study Examination of Work Family Conflict, Production Deviance and Gender. Journal of Vocational Behavior 81, $245-258$. 
Fida, R., Paciello, M., Tramontano, C., Barbaranelli, C., \& Farnese, M.L. (2015). Yes I Can: The Protective Role of PersonalSelf-Efficacy in Hindering Counterproductive Work Behavior Under Stresful Conditions. Journal Anxiety, Stres \& Coping: AnInternational Journal 28, $479-499$.

Ghozali, I. (2011). Aplikasi Analisis Multivariate dengan SPSS. Semarang: Universitas Diponegoro.Handoko, T.T.

(2001). Manajemen Personalia dan Sumber Daya Manusia. Yogyakarta : BPFE.

Hardiani, W.A.A., Rahardja, E., \& Yuniawan, A. (2020). Pengaruh Konflik Peran dan Role Overload Terhadap Burnout danDampaknya Pada Cyberloafing (Studi pada PT. PLN (PERSERO) Pusat Manajemen Konstruksi). Jurnal Visi Manajemen 5.

Huda, T.N., \& Mulyana, A. (2018). Pengaruh Adversity Quotient terhadap Prestasi Akademik Mahasiswa Angkatan 2013Fakultas Psikologi UIN SGD Bandung. PRYMPATHIC : Jurnal Ilmiah Psikologi 4, 115 -132.

Julita, S., \& Andriani, I. (2017). Dukungan Organisasi yang Dirasakan dan Keterikatan Karyawan Pada Karyawan PT. BRIcabang Banda Aceh. Jurnal Psikologi Undip 16, 40 -53.

Kanfer, R., Crosby, J.V., \& Brandt, D.M. (1988). Investigating behavioral antecedents of turnover at three job tenure levels,Journal of Applied Psychology 73, 331-335.

Lestari, N.N.Y.S., \& Mujiati, N.W. (2018). Pengaruh Stres Kerja, Komitmen Organisasi, dan Kepuasan Kerja Karyawan Terhadap Turnover Intention. E-Jurnal Manajemen Unud 7, 3412 - 3441.

Ng, T.W.H., \& Feldman, D.C. (2008). The Relationship of Age to Ten Dimensions of Job Performance. Journal of AppliedPsychology 93, 392-423.

Novan, W.D., \& Wahyuningtyas, R. (2020). Pengaruh Praktik HR Inovatif Terhadap Turnover Intention dengan Perilaku Kerja Kontraproduktif sebagai Variabel Intervening (Studi Pada Karyawan PTPN VIII Kertajaya). Jurnal Mitra Manajemen (JMM Online) 4, 1048 - 1061.

Nurfianti, A., \& Handoyo, S. (2013). Hubungan antara Keadilan Distributif dan Perilaku Kerja Kontraproduktif denganMengontrol Leader Member Exchange (LMX). Jurnal Psikologi Industri dan Organisasi 2, 183 - 190.

Puspita, A., \& Zakiy, M. (2020). Aspek Keadilan Organisasi dan Deviant Workplace Behavior Karyawan. EQUILIBRIUM:Jurnal Ekonomi Syariah 8, $41-62$.

PT. Bank BCA Syariah. (2019). Mempertahankan Kualitas dan Pertumbuhan yang Berkesinambungan: Laporan Tahunan: $80-82$.

Rohmah, S., Miftah, H., \& Yoesdiarti, A. (2020). Analisis Kelayakan Usaha Pengolahan Kopi Robusta (Coffea canephora)Pada Kelompok Tani Hutan (KTH) Cibulao Hijau. Jurnal Agribisains 6, 29 - 34.

Rotundo, N., \& Spector, P.E. (2010). Counterproductive Work Behavior and Withdrawal. In J.L. Farr \& N.T. Tippens (Eds.),Handbook of Employee Selection (pp.489-511). Routledge: Taylor \& Francis.

Sabila, F.A. (2019). Pengaruh ketidaksantunan di tempat kerja terhadap keinginan berpindah dengan keterikatan kerja sebagai variabel moderator pada karyawan perbankan. Skripsi Gelar Sarjana. Universitas Airlangga.

Sekaran, U. (2006). Research Methods For Business. Edisi 4 buku 2. Jakarta: Salemba Empat.

Soeling, P.D., \& Handoko, T. (2020). Analisa Penyebab Turnover Intention Karyawan Pada Sektor Perbankan Syariah.

Syntax Idea 2, $676-689$.

Spector, P.E., Fox, S., Penney L.M., Bruursema, K., Goh, A., \& Kessler, S. (2006). The Dimensionality of Counterproductivity: Are All Counterproductive behaviors creted equal?. Journal of Vocational Behavior 68, 446 460.

Sury, L.E. (2020). Pengaruh Kepemimpinan Islami dan Motivasi Ekstrinsik terhadap Kinerja Karyawan. Skripsi GelarSarjana. Universitas Muhammadiyah Yogyakarta.

Tarwaka. (2015). Ergonomi Industri Dasar-Dasar Pengetahuan Ergonomi dan Aplikasi di Tempat Kerja. Surakarta: HarapanPress. 
Wah, Y.B., Ramayah, T., Nushazelin, W., \& Shahidan, W. (2012). Satisfaction and Trust on Customer Loyalty: A PLS Approach. Business Strategy Series 13, 154 - 167.

World Health Organization. (2014). Protecting Workers Health. Geneva: World Health Organization Centre for Health Development.

Yang, N., Chen, C. C., Choi, J., \& Zou Y. (2000). Sources of Work-Family Conflict: A Sino-U.S. Comparison of The Effectof Work and Family Demands. Academy of Management Journal 43, 113-123.

Zahoor, I., Malik, N.I., \& Atta, M. (2019). Relationship Between Job Insecurity, Workplace Incivility, and CounterproductiveWork Behaviour Among Employees: Role of Work Family Conflict. Foundation University Journal of Psychology 3, $133-162$.

Zakiy, M. (2019). To Examine Leader-Member Exchange as Moderating Variable on The Influence of Employee Psychological Uncertainty Toward Employees' job Satisfaction and Turnover Intention. Journal of Leadership in Organizations 1, $29-47$.

Zakiy, M. (2021). SPSS Penelitian Keperilakuan: Teori dan Praktik. Prenada Media.

Zunianto, M., \& Fauzan. M. (2017). Pengaruh sustainability report terhadap kinerja keuangan perusahaan, kinerja pasar, dannilai perusahaan. Skripsi Gelar Sarjana. Universitas Muhammadiyah Yogyakarta.

Conflict of Interest Statement: The authors declare that the research wasconducted in the absence of any commercial or financial relationships that could be construed as a potential conflict ofinterest.

Copyright (C) tahun terbit nama belakang and nama belakang. This is an open-access article distributed under the terms of the Creative Commons Attribution License (CC BY). The use, distribution or reproduction in other forums is permitted, provided the original author(s) and the copyright owner(s) are creditedand that the originalpubli-cationin this journal is cited, inaccordance with accepted academic practice. No use, distribution or reproduction is permitted which does not complywith these terms. 